\title{
The function of poetic speech in the narrative in Daniel 2
}

\author{
P M Venter \\ University of Pretoria
}

\begin{abstract}
Two poetic sections are identified and investigated in Daniel 2. Attention is paid to the function of these poems within the narrative in Danicl 2 and its particular structure. The conclusion is drawn that poetic speech is used here as a focusing technique to point out the main themes of the narrative.
\end{abstract}

\section{INTRODUCTION}

Towner demonstrated 'the logical and theological coherence of the narratives of Daniel 2, 4, and 6 with the short poetic prayers or psalms imbedded in them' (Towner 1969:317). Watts (1992:12) included Daniel 2:20-23 in his study of 'narratively inset psalmody'.

Both Towner and Watts used a form-critical approach in their studies. Towner's analysis of the poetic passages is in essence form analysis. He concludes that all of these poetic passages 'imitate, one or another of the stereotyped forms of Old Testament prayer' (Towner 1969:322). Watts worked with 'hymns' and restricted his study to those poetic passages which are Psalm-related, having very near the same contents as the Psalms. According to Watts, it is especially the element of praise which distinguishes these hymns from other poetic passages in the Bible. In both these studies the analysis of the poems was form-critical in nature. No attention was paid to the poetic structure of the passages. Although the form-critical aspect is of great importance in studying these passages, a more comprehensive approach

This paper was read at the SBL Congress at Münster in Germany on 27 July 1993. 
should be followed. There is much more to 'what makes poetry poetic' (Petersen $\&$ Richards 1992:7), than just recognizing typical forms and themes.

Both scholars treated the poetic passages, and the narratives in which they are embedded, as essentially coherent. According to their common viewpoint the poems have a definite function in the surrounding narratives. According to Towner (1969:322) the poetic passages in Daniel '...function as theological epitomes...' and '...focus the point of the narratives...'. Unfortunately he did not analyse the narratives, or at least show the reader how he reached his conclusion on the themes of the narratives. Watts did include narrative analysis in his study to determine the function of the inset hymns. He explored the narrative role of the 'inset hymns' on three different levels 'in an attempt to determine the reasons for its present position' (Watts 1992:14). These levels are the function of the psalm in the plot of the narrative, the degree to which the psalm and its immediate context share common themes and vocabulary, and the contribution of the psalm in characterizing the person who utters it. In the case of Daniel 2:20-23 he comes to the conclusion that this inset hymn plays no part in the development of ${ }^{*}$ e plot. Its main purpose, however, is to characterize God. This is the central theme of the proximate narrative context. It is also designed to picture Daniel as a model of piety (Watts 1992:148-149). Formulating it in this way Watts narrowed the scope of his narrative analysis to characterization. Again I would suggest that there is more to the analysis of a text than merely dealing with only one or two aspects of narrativity. The artistic text as multiply encoded text' (Lotman 1977:59) comprises much more than common themes and words between poetic and prose sections. Every aspect used by the author to structure meaning into the text should be studied.

Using a comprehensive literary approach, the starting point of our analysis of Daniel 2 should be the final Aramaic text, as printed in the Biblia Hebraica Stuttgartensia. The poetic parts in the narrative are to be identified first. The criterion for identification is the simple question as to whether any typical poetical elements are present and, if so, whether these form 'a complex of heightening effects' (Kugel 1981:94) in which equivalence between the elements rather than sequence has prominence. Rather than any single typical or even one dominant element (like 'emphatic repetition' [Kugel 1981], or 'incremental repetition' [Alter 1985], or 'terseness' [Berlin 1985]), a wide variety of elements are intended. These are elements from which a poet chooses and which he then arranges according to the basic ordering mechanism of parallelism (Lotman 1977:166) to create equivalence or paradigmatic relationship between all signs in the text on every level of the poem, whether morphologic, syntactic, semantic. In this way 'contiguity is created on all levels of vertical ordered poetic lines' (Nel 1989:68-69, my translation) or to put it in 
some other way: 'correspondence, on any and every linguistic level' (Landy 1984:75). Two sections can be identified as poetry in Daniel 2:20b-23 and 47b-e. The poem in verses $20 \mathrm{~b}-23$ consists of 22 stiches, 11 lines, 7 strophes and 2 stanzas. Focusing on the level of the strophes and stanzas, a specific pattern emerges:

Stanza A

Strophe 1:

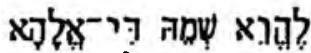

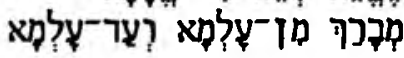

Strophe 2:

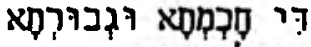

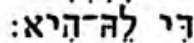

Strophe 3:

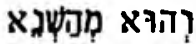

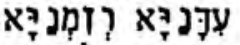

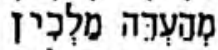

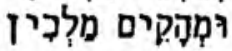

Strophe 4:

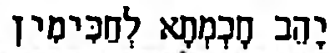

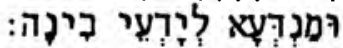

Strophe 5:

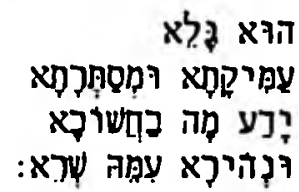

\section{Stanza A}

Strophe 1:

Let the name of God

be praised for ever and ever;

Strophe 2:

because wisdom and strength

belongs to him;
Stanza B

Strophe 6:

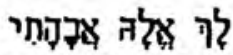

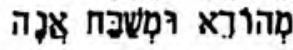

Strophe 7:

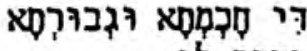

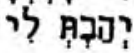

[Strophe 7:]

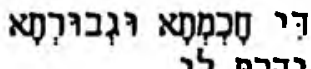

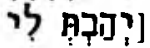

Strophe 8:

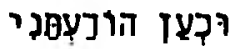

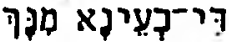

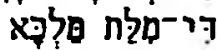

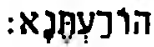

\section{Stanza B}

Strophe 6:

You God of my fathers

honour and praise I;

Strophe 7:

for wisdom and strength

you gave to me; 
Strophe 3:

and $\mathrm{He}$ is the one who changes

times and seasons;

He deposes kings

and $\mathrm{He}$ appoints kings;

Strophe 4:

He gives wisdom to the wise and knowledge to the discerning:

Strophe 5:

$\mathrm{He}$ is the one who reveals deep and hidden things; He knows what lies in darkness and light dwells with him.
Strophe 7:

for wisdom and strength

you gave to me;

Strophe 8:

and now you have made known to me what we asked from you; the dream of the king you have made known to us.

The first stanza (A) comprises 5 strophes. Strophe 1 is substantiated by the contents of the other four. Praise is given to God because he has wisdom and he provides knowledge of hidden things. The term 'wisdom' occurs in both strophes 2 and 4 . In Strophe $2 \mathrm{God}$ has wisdom and in strophe 4 God gives wisdom. This pattern of having and giving is repeated in inverted order between strophes 4 and 5 , this time linked to the knowledge which God gives and which he has. God gives knowledge to the discerning in strophe 4 , while in strophe 5 he has knowledge of what lies in the dark. Strophes 2, 4 and 5 therefore show a chiastic pattern bringing together God's wisdom and knowledge as something which $\mathrm{He}$ has in store and which he gives to people. Equivalence is created between God having and God giving wisdom. This in turn is the reason for praising him in strophe 1.

Strophe 3 obviously presents a problem. It deals with God's power to be in command of everything. By means of alliteration at the level of sound, word repetition and the use of word pairs at the level of words, and similar word order at the level of sentences, a closely knitted strophe is formed, linking changing times and changing kings, putting both under God's command. These thoughts, however, are not repeated or even hinted at in the rest of the poem. There are two reasons why it cannot be read as a mere synthetic parallel extension on the theme of God's wisdom and strength in the previous line. The first reason is that the fixed word pair, wisdom and strength, operates as the equivalent of knowledge in all of the poem. The 
word pair is repeated in strophe 7 , where it is paralleled to knowledge in the next strophe 8 . The same occurs where wisdom and strength in strophe 3 is made synonymous with knowledge in strophe 4 . The inserted strophe forms an off-centre insertion between two strophes which belong together. The second reason is that the second stanza has exactly the same order as the first: benediction, wisdom, revelation. Strophe 3 deviates from this pattern. It does not have any counterpart in the poem like the other strophes. According to my mind this puts strophe 3 and its specific theme in an extraordinary although related position in the poem. It links up to the theme of God and what he does (he has and gives wisdom and knowledge) but deals with a different aspect of God's doings. Even if this strophe is treated as a later addition to the poem, or a redactional note, the relatedness to the poem must be acknowledged. The question, however, remains: Why was this strophe inserted in the poem and why at exactly this place? Whether the original poet, or a later redactor, somebody included that strophe in the poem because he wanted to state some equivalence between the form and contents of that neatly structured strophe and the rest of the poem. This dictum/enunciation on God's ability to change times and kings was inserted not directly after strophe 1 , but after strophe 2 , to include it in the chiasmus on God having and God giving wisdom and knowledge. We shall deal with the meaning of this when we analyse the function of the poem in the narrative.

Stanza B is parallel to the first stanza. It has the same subjects, which are presented in the same order.

Stanza A

Strophe 1:

benediction

Strophe 2:

wisdom and strength

Strophe 4:

wisdom and knowledge

Strophe 5:

revelation

\section{Stanza B}

Strophe 6:

benediction

Strophe 7:

wisdom and strength

An obvious shift takes place in this stanza. In stanza A God has wisdom and knowledge and he gives wisdom and knowledge. In stanza $B$ the aspect of having is not repeated, only the aspect of God giving wisdom and knowledge. What is more, a dialectical you-I theme is introduced here. The stanza is framed by a 'you' and an 'I'. The stanza starts out with the second-person pronoun and it ends with the firstperson pronominal suffix. Each line contains an interplay between you' and 'T': 


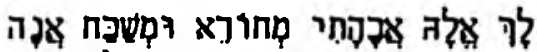

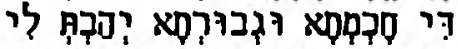

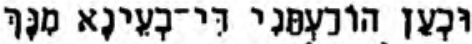

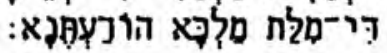

You God of my fathers honour and praise I;

for wisdom and strength you gave to $m e$;

and now you have made known to me what we asked from you;

the dream of the king you have made known to us.

Another recognizable shift is from the participium form of the verbs in stanza $A$ to the perfect form in stanza B. What God always is and does is now confirmed by what he did for Daniel and his friends. Thus contiguity is created in the poem, repeating and refining what has been stated in the first stanza within the particular relation between God and those who depend on him pictured in stanza B. God is praised in this poem because he knows everything and he reveals secret things to his wise men. Linked to this theme is the idea, expressed in strophe 3 , that he is also in control of everything.

The poetic part of the speech of the king in verse $47 \mathrm{~b}$-e echoes the main themes of the poem in verses 20 to 23 (cf Collins 1984:50-51). According to Collins it even sums up the point of Daniel 2 (Collins 1975:220). Words used in the poem, like 'God' and 'king', and ideas like 'reveal' and 'secret', are repeated here.

The poetic part of the speech can be divided into two strophes:

1. Truly, your God

he is the God of the gods

and the lord of the kings

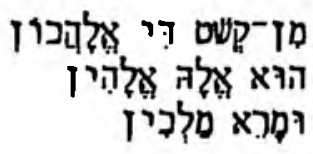

רגליה כוקין

2. and he reveals secrets.

Again God is praised as the one who is in control of gods and kings. This is substantiated by his ability to reveal hidden things. The two main elements are God's sovereign rule and his ability to give revelations. And those are exactly the same elements found in Daniel's poem in verses 20-23. The king's poetic speech forms a parallel to Daniel's benediction and, by means of repetition of words and themes, equivalence exists between them. 


\section{THE NARRATIVE}

The results of our analysis of the poetic sections lead to a next step in the investigation. These poetic passages are included in a still larger structure which is of a nature different from the poems with their inclination towards equivalence of elements. The 'multiply encoded text' (Lotman 1977:59) in which they are found is marked by a tendency towards sequence in its elements. It has a narrative structure showing all the elements and techniques used to tell a story. An answer to the question of the function and meaning of these poems depends on a narrative analysis of the larger structure in which they operate.

We take as our point of departure Genette's model which sees narratives as literature operating on three different levels, with a multiplicity of interlinked elements. Analysis of the narrative consists of investigation into these elements, the relationship between them and the relationship between the difterent levels on which the narrative operates. The three levels are those of the mere events (the 'story' or 'histoire'), the presentation of those events in a structured text ('discourse' or 'récit') and what happens when this text is read or heard ('narrative event' or 'narration').

The basic 'story' (as Ska 1990:5-6 uses the term) in Daniel 2 is actually very simple. It is the typical folktale situation where nobody is able to solve a specific problem save one gifted person. King Nebuchadnezzar has had a dream. He tries everything in his power to persuade his officials to tell him what he dreamt and what it means. They are unable to meet his demand, because it is humanly impossible. Being unsuccessful in his efforts, the king brings about a crisis in Babylon by giving an order to kill all the wise men in his kingdom. Daniel and his friends are to be executed as well. They pray to God and he reveals the dream and its meaning to Daniel. Daniel then tells the king what he dreamt and explains his dream to him. The king's demand been met, the crisis comes to an end and Daniel and his friends are richly rewarded for solving the problem.

These events are narrated in a discourse which has three episodes and eight scenes. In episode 1 , scene 1 (verse 1 ), the king is introduced as having had a bad dream. In scene 2 (verses $2-13$ ) the crisis develops when no-one is able to tell the king what he dreamt and what it means. It ends in the king's decision to have all the wise men in his kingdom executed. In episode 2, scene 3 (verses 14-16), the protagonist Daniel is introduced. In scene 4 (verse 17-23) the hero gets help from God, the dream is revealed to him and a provisional solution is reached for the problem. In episode 3, scene 5 (verses 24-28), Daniel appears before the king and offfers to solve the riddle. In scene 6 (verses 29-36) Daniel tells the king what he saw in his dream. It was a large statue made from different materials, which was destroyed in the end. In scene 7 (verses $36-45$ ) he explains to the king that this statue is a symbol 
of what will happen in future to him and his kingdom. It will eventually be destroyed by God. In the final scene, number 8 (verses 46-49), the king acknowledges the power of God and his ability to reveal the future. Daniel and his friends are rewarded by being given favourable positions in the administration of the king, Daniel himself being promoted to a position of influence in the court of the king himself.

The plot is not only literally a plot about a revelation, but it is also what Chatman would call a 'plot of revelation' (cf Ska 1990:18). The action in the plot is not as important as the information which is revealed by the plot. Using a form of Greimas' actantial model to analyze the basic plot of the story the king appears as the one who sends or launches the action. The object of the action is to find the dream and its meaning. The one who helps to attain that goal is Daniel who acts with the help of God. The plot ends and the action comes to an end when the king has heard the dream and its meaning. The dream and its meaning forms the theme of the narrative. It is the Leitmotiv of the plot, as can be seen from the multiple use of the word pair 'the dream and its meaning' and its variants (the riddle, the matter of the king). Dream and its meaning means more in this plot than simply having a nocturnal experience. To the king it is a divine revelation about the future. This becomes clear when the king insists that he be told both the drearn and its meaning. In a 'sequence of action' (Alter 1981:95) in episode 1, the king three times demands that he wants to hear both the dream and its meaning, not only its interpretation. The crisis gradually develops when the king's officials twice declare their willingness to provide the king with an interpretation if only he will tell them what he has dreamt (like Pharaoh's men in Genesis 41). The third time they explicitly tell the king that he wants something which only the gods can give him. The object the king is looking for is actually a divine revelation. Daniel presents his communication about the dream and its meaning as a revelation from the God of heaven to king Nebuchadnezzar about the future. The king accepts these words as the divine revelation he was looking for. The objective of the sender has been found and the plot ends.

But there is still more to the theme than the divine revelation the king was looking for. This theme also has a second level of meaning. Halfway through the narrative the action already reaches a turning point. Daniel has been informed about the king's dream and the crisis can be resolved. From that point the attention shifts to the contents of the dream and its meaning. In fact, sixty-six percent of the total discourse time is spent in scenes 6 and 7, telling what the contents of the dream and its future meaning are. This Leitmotiv means more than the divine revelation the king was looking for. It also means the contents of the revelation. This becomes clear when the contents and meaning of the dream are reported extensively in the second part of the narrative. 
This second level of meaning is brought about by a shift in focalization in the second half of the narrative. In the first half everything is described from the viewpoint of the king and what he is looking for. In the second half the discourse is presented from the view point of Daniel who solves the crisis with the help of God. This represents a shift from the divine revelation desired, towards the content and meaning of that revelation in terms of the God who gave it. Crane distinguishes between plots in which a change of knowledge, values or situation takes place (cf Ska 1990:19). In this plot a change of knowledge takes place. The king gets hold of the knowledge he seeks. But there is an ironic difference between what the king gets to know and what God has told Daniel. The king wants to know what will happen to his kingdom. What is interesting is that he ignores the contents of the prophecy and does not react to Daniel's interpretation at all. It is Daniel's wisdom and his God's ability to reveal the future which impresses him most (cf Collins 1975: 220). It is merely the fact that he has received a divine revelation that satisfies him. He is not really interested in its content. He praises Daniel's God as the major God because he was able to give him the revelation he sought. It seems that he did not grasp the real meaning of the revelation, that his kingdom will eventually be destroyed by this God's kingdom. What the king reacts to and what Daniel really conveys are two different fields of knowledge. An ironic contrast therefore appears between the knowledge the king has and what Daniel knows.

This contrast operates on another level as well. There is also an ironic contrast between the king and the reader. The narrator manipulates his (implied) readers to take an active part in the narrative event. One of the techniques the narrator in this narrative uses is to give an internal focalization, to let the reader see matters from Daniel's point of view. Daniel has an ideological viewpoint which goes beyond the mere revelation the king was looking for. He focuses on God, the Revealer himself. It is from his viewpoint that the narrator makes the hearer or reader see what is really happening. The personal way in which Daniel is presented in the narrative moves the reader to become interested in Daniel's viewpoint. More than that, the reader is motivated to identify with Daniel and to develop idealistic empathy with him. Daniel is the sage who knows what the reader wants to know. Along with Daniel the reader gains knowledge of God's superiority, which Nebuchadnezzar seems to have missed. An ironic situation develops which can be described as one of 'dramatic irony' (cf Ska 1990:57-61) or 'situational irony' (Powell 1990:30). There is 'a contrast between the inaccurate perception of a situation by at least one character and the perception of the real situation by the reader' (Ska 1990:60). In this plot everyone gets to know that God reveals secrets. But only Daniel and the readers get to know that God also reigns over kings and kingdoms. 
Several other strategies are used in the narrative to develop this second level of meaning. One of these is the way in which the setting operates in the plot. Everything takes place in and around the court of the king in Babylon. This is an enclosed space where everything is directed by the king. He decides on what should happen and he brings about the crisis when his demands are not met. The space of the narrative is focused on royal power and might. But the king, with all his power, is unable to enforce the divine revelation he is looking for. The crisis is only resolved when Daniel appears on the scene and he receives the information from God needed to meet the king's demands. The king is confronted with another kingdom, which surpasses his own. He meets the King of kings, who decides who will be king and what will happen in future. Ironically the narrative itself remains in the sphere of the king and his court, right to the end. It is Nebuchadnezzar who decides that Daniel has truly given a divine revelation and he rewards him by appointing him as leader of the wise men. But the reader is left with the knowledge that the king has only acted according to the powers granted to him by God. His kingdom will only last for as long as God has decided.

The most important strategy used in the narrative to develop a second level of meaning is the use of more than one narrator. At the basic level we hear the voice of a narrator who is undramatized, who is telling from an omniscient point of view in the third person, who looks back on what has happened and does not give any comment on it. He tells the story from 'outside' and keeps his distance by, inter alia, using titles like 'the king', 'the wise men'. But when it comes to Daniel, the narrator only uses his personal name. He stands much closer to Daniel and gives the reader a hint of whose viewpoint he shares. This trend is strengthened when the author lets his narrator make Daniel tell his own story within the larger story. Daniel is introduced as narrator on a second level or second diegesis. What he says is imbedded in the larger narrative and functions on a metadiegetic level. As is most often the case, "the "embedded" narrative may be thematically more important than the one framing it' (Genette 1988:90).

What Daniel tells forms this second level of meaning we referred to. Daniel's speech lies on a second level. It has what Genette would call '...the predictive function of a metadiegetic prolepsis, telling not the antecedent causes but the subsequent consequences of the diegetic situation...' (Genette 1988:93). There are two occasions on which Daniel acts as narrator. The first occurs in the 'narrative pause' (Grâbe 1990:53) in scene 4 (verse 17-23) where Daniel's 'inner life' (cf Ska 1990:91) is presented in a lyrical text. His benediction functions on an intradiegetic level, expressing his gratitude for what God has done for him. In a 'flashback' he recalls how God gave him wisdom and revealed the king's secret to him. He expresses his belief 
in God's power to rule and his ability to reveal secrets. The second occasion occurs in scenes 6 (verses 29-36) and 7 (verses 36-45). Here Daniel narrates what the king saw in his dream. On a heterodiegetic level he tells about the statue and what happened to it. This 'statue narrative' is repeated a second time in scene 7 with the meaning of the dream added. The repetition of the narrative each time follows the same order. They form a parallel pair framed by the phrase 'what will occur after this' at the beginning of the first one and at the end of the second one. Both are a prolepsis of the destruction of Nebuchadnezzar's kingdom. The plot centres on the continuation of the kingdom. Because of inherent weaknesses as well as God's eventual intervention, the kingdom comes to an end. The protagonist in these events is God, who installs Nehuchadnezzar on the throne, but who changes times and seasons and disposes of this kingdom in the end - the theme we had in strophe 3 of the poem in verses $20 \mathrm{~b}-23$. Within the basic narrative of a king who looked for a divine revelation and found it, a second level of meaning is created when one of the characters gives the revelation in the form of a story in which the supreme power of God to install and dispose of kings and to make things change, is narrated. This theme forms an extension on the basic theme that God is capable of revealing the future.

\section{THE FUNCTION OF THE POETIC PASSAGES IN DANIEL 2}

In Daniel's benediction (verses 20-23) God is praised because he has wisdom and reveals the future to God-fearing and wise men. Included in the structure of the poem in such a way to distinguish it from this theme, but simultaneously make it congruent to it, is found the theme of God's sovereign rule. These two parallel themes are echoed in the speech of the king in verse $47 \mathrm{~b}-\mathrm{e}$. The king praises God because he (God) controls gods and kings and has the power to reveal hidden things. These two themes are also the themes of the narrative in which they are embedded. But they operate on different levels. The basic theme of the narrative is the dream and its meaning. This is the object searched for and found in the plot. God gives that revelation and the king's problem is solved. The poem refers to that theme and makes it explicit to the reader. But the narrative as 'narration' operates on a second level. It tells about God's supremacy and his superiority over the kingdom of Nebuchadnezzar. This is the theme found in the off-centre position in the poem and in Daniel's communication on the dream and its meaning. And this is the most central theme of the narrative. 
Works cited

Alter, R 1981. The art of Biblical narrative. New York: Basic Books.

--- 1985. The art of Biblical poetry. New York: Basic Books.

Berlin, A 1985. The dynamics of Biblical parallelism. Bloomington: Indiana University Press.

Collins, J J 1975. The court-tales in Daniel and the development of apocalyptic. $J B L$ 94, 218-234.

..- 1984. Daniel with an introduction to apocalyptic literature. Grand Rapids: Eerdmans.

Crane, R S 1952. The concept of plot and the plot of 'Tom Jones', in Crane, R S (ed), Critics and criticism. Chicago.

Genette, G 1988. Narrative discourse revisited. Ithaca: Cornell University Press.

Gräbe, I 1990. Theory of literature and Old Testament studies - poetic and narrative conventions as exegetic reading strategies. OTE 3, 43-59.

Kugel, J L 1981. The idea of Biblical poetry: Parallelism and its history. New Haven: Yale University Press.

Landy, J 1984. Poetics and parallelism: Some comments on James Kugel's 'The idea of Biblical poetry'. JSOT 28, 61-87.

Lotman, J 1977. The structure of the artistic text. Michigan: University of Michigan Press. (Michigan Slavic Contributions No 7.)

Nel, P J 1989. Ou-Testamentiese poësie: Metodologie en perspektief. Acta Academica 21/3, 61-77.

Petersen, D L \& Richards, K H 1992. Interpreting Hebrew poetry. Minneapolis: Fortress. (Guides to Biblical scholarship. Old Testament Series.)

Powell, M A 1990. What is narrative criticism? Minneapolis: Fortress. (Guides to Biblical scholarship.)

Ska, J L 1990. 'Our Fathers have told us': Introduction to the analysis of Hebrew narratives. Roma: Editrice. Pontificio Istituto Biblico. (Subsidia Biblica 13.)

Towner, W S 1969. The poetic passages of Daniel 1-6. CBQ 31, 317-326.

Watts, J W 1992. Psalm and story: Inset hymns in Hebrew narrative. Sheffield: Sheffield Academic Press. (JSOT, Supplement Series 139.) 